\title{
Problematika Stay At Home Pada Anak Usia Dini Di Tengah Pandemi Covid 19
}

\author{
A. Tabi'in \\ Pendidikan Islam Anak Usia Dini (PIAUD) IAIN Pekalongan \\ ahmadtabiin6@gmail.com
}

\begin{abstract}
Abstrak:
Munculnya virus covid-19 di Indonesia mempengaruhi aktivitas anak-anak yang harus ikut berdiam diri di rumah guna mencegah penularan virus secara meluas. Anak-anak yang semula melakukan aktivitas bebas di luar rumah sekarang berbanding terbalik yaitu mereka harus beraktivitas di dalam rumah. Penelitian ini di latar belakangi dari adanya problematika anak-anak stay at home, belajar di rumah, bermain di rumah serta aktivitas apapun dilakukan di rumah selama masa pandemi belum berakhir. Penelitian ini bertujuan untuk mengetahui problematika yang muncul pada anak-anak yang ikut berdiam diri di rumah atau stay at home. Anak-anak pada dasarnya tidak bisa untuk berdiam diri karena dimasa ini adalah masa eksploratif atau penjelajah. Metode yang di gunakan dalam research ini adalah pendekatan kualitatif deskriptif dengan teknik pengumpulan data menggunakan wawancara, observasi, dan dokumentasi. Setelah itu diproses melalui triangulasi data. Berdasarkan hasil temuan penelitian anak-anak TK Puspita Subah mengalami beberapa masalah ketika stay at home, masalah-masalah itu diantaranya, Stres, sensitifitas meninggi, temper-tantrum, manja/tidak mandiri dan gangguan perilaku.
\end{abstract}

Kata kunci: Stay At Home, Anak Usia Dini, Covid 19

Abstract

The emergence of covid-19 virus in Indonesia affects the activities of children who have to stay at home to prevent widespread transmission of the virus. Children who originally did free activities outside the home are now inversely proportional they have to move inside the house. This research is based on the problematic of children staying at home, studying at home, playing at home and any activities carried out at home during the pandemic period. This study aims to determine the problems that arise in children who come to stay silent at home or stay at home. Children basically cannot be silent because this is an explorative or explorer period. The method used in this research is a descriptive qualitative approach with data collection techniques using interviews, observation, and documentation. After that it is processed through data triangulation. Based on the research findings of Puspita Subah Kindergarten children experiencing some problems when staying at home, the problems include, Stress, heightened sensitivity, temper tantrums, spoiled/not independent and behavioral disorders.

Keywords: Stay At Home, Early Childhood, Covid 19.

Problematika Stay At Home (Tabi’in) 


\section{PENDAHULUAN}

Saat ini dunia dikejutkan dengan mewabah suatu penyakit yang di sebabkan oleh sebuah virus yang bernama corona atau dengan nama lain covid-19 (corona virus diseases-19). Virus yang disinyalir mulai mewabah pada kisaran Desember 2019 di kota Wuhan Provinsi Hubai Tiongkok, Saat ini menyebar hampir keseluruh dunia dengan sangat cepat hingga otoritas kesehatan dunia WHO pada tanggal 11 Maret 2020 menetapkan wabah ini sebagai pandemi global. Di indonnesia virus corona mulai masuk pada tanggal 2 Maret 2020 hal ini di ungkapkan oleh presiden Indonesia Ir Joko Widodo dalam siaran persnya. Pada awal mula virus corona masuk di Indonesia melalui virus corona itu didapat dari warga negara Jepang yang sempat melakukan perjalanan di Indonesia. Dia kemudian menularkan itu ke pasien Kasus satu, lalu virus corona itu sampai ke pasien kasus dua. Penyebaran virus corona pada mulanya sangat berdampak pada dunia ekonomi yang mulai lesu karena para pekerjaa banyak yang diliburkan, pabrik-pabrik menutup diri, serta daya beli masyarakat sangat rendah. Akan tetapi kini dampaknya juga sangat dirasakan oleh dunia pendidikan.

Pemerintah pusat dan daerah mengambil kebijakan secara tegas bahwa sekolah diliburkan. Hal ini seperti negara-negara lain yang sudah terlebih dahulu terkena dampak corona. dengan meniadakan seluruh aktivitas pendidikan, membuat pemerintah dan lembaga terkait harus menghadirkan alternatif sebagai proses pendidikan bagi peserta didik maupun mahasiswa yang tidak bisa melaksanakan proses pendidikan pada lembaga pendidikan. Diharapkan seluruh lembaga pendidikan tidak melaksanakan aktivitas seperti biasanya. Hal itu dapat meminimalisir penyebaran penyakit Covid-19 ini. Hal serupa juga sudah dilakukan sudah dilakukan beberapa negara yang terpapar penyakit Covid-19 ini. Kebijakan lock down atau karantina dilakukan sebagai upaya mengurangi interaksi banyak orang yang dapat memberi akses pada penyebaran virus corona (Yurianto, Ahmad, 2020).

Aktivitas yang melibatkan kumpulan orang-orang kini mulai dibatasi seperti bersekolah, bekerja, beribadah dan lain sebagainya. Pemerintah sudah mengimbau untuk bekerja, belajar, dan beribadah dari rumah untuk menekan angka pasien yang terpapar COVID-19. Menteri Nadiem Anwar Makarim menerbitkan Surat Edaran Nomor 3 Tahun 2020 pada Satuan Pendidikan dan Nomor 36962/MPK.A/HK/2020 tentang Pelaksanaan Pendidikan dalam Masa Darurat Coronavirus Disease (COVID-19) maka kegaiatan belajar dilakukan secara daring (online) dalam rangka pencegahan penyebaran coronavirus disease (COVID0-19). (Menteri Pendidikan, 2020)

Penutupan sekolah-sekolah dan kampus tersebut tentu dapat menghambat dan memperlambat capaian target yang sudah ditetapkan oleh pemerintah dan atau sekolah masing-masing. Pastinya, kondisi demikian akan mengganggu pencapaian kematangan siswa dalam meraih tujuan belajarnya, baik secara akademis maupun psikologis. Yang lebih mengkhawatirkan lagi adalah dampak psikologisnya. Siswa yang harus tertunda proses pembelajarannya akibat penutupan sekolah sangat 
memungkinkan akan mengalami trauma psikologis yang membuat mereka demotivasi dalam belajar. Demikian halnya dengan pembatalan beberapa agenda dan program penting siswa ke luar negeri seperti perlombaan dan studi overseas membuat mereka kecewa karena mereka merasa telah mempersiapkan jauh-jauh hari sebelumnya. Apalagi wawasan para siswa seputar virus corona masih minim yang bisa membuat mereka memiliki tingkat kekhawatiran yang lebih tinggi.

Salah satu himbauan untuk menahan lajunya penyebaran Covid-19 adalah tetap tinggal di rumah. Himbauan yang awalnya muncul dalam bentuk tagar stay at home dan dikuti oleh tagar di rumah aja yang cukup viral didunia maya. Ditambah dengan adanya himbauan pemerintah untuk bekerja dari rumah atau work from home (WFH) maka praktis sejak merebaknya Covid-19 di Indonesia sampai hari ini masyarakat mulai menerapkan tetap tinggal di rumah, tidak kemana-mana. Artinya sebahagian besar orang saat ini menghabiskan waktu di rumah bersama keluarga.

Meski kebijakan diam di rumah untuk mencegah penyebaran Covid-19 menjadi kesempatan untuk kumpul bersama keluarga, tetapi ada beberapa tantangan yang dihadapi orangtua dalam mendampingi anak. Tantangan itu mulai dari kebosanan yang mungkin dirasakan anak-anak, kemampuan orangtua untuk menggantikan peran guru di sekolah, hingga fasilitas yang dimiliki. "Apakah kita punya kemampuan untuk mengasuh anak kita? Salah satunya adalah kebosanan (anak)," kata Child Protection Specialist UNICEF Indonesia, Astrid Gonzaga Dionisio dalam konferensi pers di BNPB, Kamis (2/4/2020). " Anak kita adalah anak yang dinamik, enerjik, sesuai perkembangannya ingin dekat teman-temannya. Apalagi anak remaja yang lebih nyaman bersama teman sebaya dibandingkan orangtua. (Suryani 2007).

Kondisi saat belajar juga menjadi tantangan. Terlebih, dalam hal belajar ada anak-anak yang lebih mempercayai guru dibandingkan orangtua. Dalam kondisi diam di rumah atau stay at home seperti saat ini, kata dia, mau tidak mau orangtua harus menjadi guru bagi mereka secara penuh. "Saat belajar, apakah kita bisa dan punya kemampuan untuk mendampingi anak-anak kita? Full time kita harus jadi guru dalam keluarga kita,. Selain itu, terkait fasilitas juga harus diperhatikan. Apalagi saat ini diberlakukan belajar secara online dari rumah. (Ade Nasihudin Al Ansori, 2020) Namun, fasilitas tersebut akan menjadi kendala bagi anak-anak yang berasal dari keluarga rentan yang memiliki keterbatasan fasilitas. Ketiak sediaan fasilitas ini akan memberi dampak kepada anak sehingga ia mendapatkan nilai tidak baik hingga risiko bullying. "Kami dapat informasi dari daerah. Bagi keluarga rentan, stay at home itu berarti ada pembatasan dari mata pencaharian yang dampaknya pada kelangsungan hidup mereka," kata dia. " Orangtua harus keluar rumah untuk bisa mencari sesuap nasi sehingga anak-anak tidak ada yang mengawasi. Siapa yang mengajari anak-anak belajar. Kondisi seperti itu, membuat anak-anak tersebut juga menjadi rentan terpapar Covid-19 yang saat ini merajalela. Dari segi pengasuhan, orangtua di rumah bisa cukup membuat stress karena tugas di rumah menjadi bertambah. Dari yang awalnya hanya memikirkan bagaimana

Problematika Stay At Home (Tabi'in) 192 
belanja, memasak, memberikan hal-hal untuk mempersiapkan anak kita sekolah tapi sekarang kita juga harus dampingi mereka, Anak-anak sekarang mungkin punya pemikiran lebih jauh dibanding kita. Seseorang yang sangat ingin dampingi anaknya itu jadi sangat stresful, apalagi kalau tidak ada yang membantu. Siapa yang harus bantu kita saat ini.

Terkait hal ini, beberapa waktu belakangan peneliti sering menemukan berbagai cerita dari para orangtua terutama ibu ibu mengenai anak anak selama stay at home bahwa anak sudah mulai bosan dengan keadaan hal ini tentunya menjadi problem orang tua karena mereka harus meramu strategi supaya anak tidak bosan. Kebosanan pada anak tidak terlepas karena anak mempunyai sifat eksplorasi tidak bisa hanya untuk diam di rumah, pada anak usia dini usia 4 sampai 6 Tahun anak sedang senang-senangnya untuk bermain dengan banyak teman.

Menghadapi perubahan tersebut secara mendadak dapat menyebabkan rasa stres. Begitu juga dengan anak-anak yang saat ini harus lebih banyak berdiam diri di rumah. Padahal sebelum adanya wabah virus corona baru anak-anak terbiasa dengan rutinitas sekolah dan main bersama dengan teman-temannya. Menurut psikiater anak dan remaja, Renvil Reynaldi, perubaham situasi ini memberikan dampak psikologis pada anak. Sebab hal-hal yang biasa dilakukan untuk sementara waktu harus dihentikan. Situasi ini dapat menyebabkan anak menjadi stres karena mereka harus berdiam diri di rumah dalam jangka waktu lama, aktivitas terganggu, dan merenggut kesempatan bereksplorasi dengan lingkungan. Anak-anak tidak sama dengan orang dewasa. fungsi kognitif atau pemikiran anak belum sesempurna orang dewasa dan memiliki keterbatasan. Bila orang dewasa dihadapkan dalam situasi harus berdiam diri di dalam rumah dalam jangka waktu lama, mereka bisa lebih memahami karena sudah berpikir tentang dampak di masa sekarang dan masa depan.(Wijayanti and Akbar 2018). Berdasarkan penjelasan dari permasalahan diatas peneliti tertarik untuk mengkaji penelitian secara mendalam terkait dampak stay at home yang di alami oleh anak usia dini lebih khusus pada anak TK Puspita Kalimanggis Subah Batang.

\section{METODOLOGI PENELITIAN}

Metode penelitian yang digunakan dalam penelitian ini adalah kualitatif deskriptif. Penggunaan pendekatan kualitatif digunakan untuk memperoleh pemahaman mendalam tentang problematikan stay at home pada anak-anak khusunya anak TK Puspita Kalimanggis Subah Batang. Kemudian, hasil penelitian dideskripsikan serta pemahaman dalam bentuk ungkapan bahasa yang tepat dan sistematis berdasarkan fakta-fakta yang ada dalam penelitian. Pendekatan kualitatif memiliki beberapa strategi yang spesifik, yang dalam penelitian ini menggunakan studi fenomenologis. Creswell menyatakan bahwa studi fenomenologis memberikan pemaknaan umum dari sejumlah individu terhadap berbagai pengalaman hidup terkait konsep dan fenomena (Creswell, 2015: 105). Penelitian ini memahami permasalahan secara mendalam terkait dengan problem-problem yang muncul pada anak-anak ketika stay at home. Studi fenomenologis ini

Problematika Stay At Home (Tabi'in) 193 
membantu peneliti menemukan esensi dari problematika stay at home pada anakanak, dimana anak-anak sangat tertekan secara psikologis tidak bisa beraktivitas di luar rumah. Penelitian ini dilakukan pada anak-anak TK puspita Usia 4-6 tahun sejak mereka di anjurkan untuk stay at home oleh pemerintah kabupaten batang tepatnya tanggal 15 Maret 2020. subjek penelitian yaitu arang tua atau wali murid anak TK Puspita yang ditentukan secara purposive sampling.

Metode pengumpulan data, peneliti menggunakan dokumentasi yang sesuai dengan arah penelitian, kemudian interview, serta observasi yang mendalam. Datadata yang di peroleh peneliti dari interview, dokumentasi serta observasi kemudian di olah dan dipadukan. Hal ini mempunyai tujuan untuk menghasilkan data-data yang akurat dan mampu untuk di pertanggung jawabkan keasliannya. Analisis data lakukan sejak dimulainya penelitian sampai penyusunan naskah akhir penelitian. Konsep yang digunakan dalam penelitian ini analisis mengalir (flow model analysis), yaitu konsep analisa yang meliputi tahapan-tahapan sebagai berikut; display data, pengambilan kesimpulan dan mengferifikasi (Huberman, 1992). Dalam hal ini peneliti melakukan pemeriksaan secara seksama pada kriteria tingkat kepercayaan (credibility). Melalui kriteria tersebut kemudian menggunakan triangulasi data atau pengambangan data melalui analisis-analisis yang mendalam (Moleong, 2005). Pada research ini, penulis menggunakan triangulasi diantaranya yaitu: pertama, triangulasi metode dengan menggunakan berbagai metode pengumpulan data untuk menggali data yang sejenis. Kedua, triangulasi sumber dengan membandingkan informasi yang dikatakan subyek dalam penelitian ini

\section{HASIL DAN PEMBAHASAN}

\section{Hasil Penelitian}

\section{Problematika Stay At Home Pada Anak Usia Dini di TK Puspita}

Menjalani kegiatan di rumah, isolasi, atau karantina mandiri selama masa pandemi virus corona mungkin terasa sangat menjemukan bagi setiap orang tetapi akan lebih menjenuhkan yang di alami oleh anak-anak dimana anak-anak pada usia 4-5 tahun adalah usia penjelajah dan eksploratif dimana anak tidak bisa untuk berdiam diri (Tabi'in 2017). Stay at home bagi orang tua yang menjenuhkan masih bisa di atasi oleh beberapa aktivitas, lain halnya dengan anak-anak, aktivitas yang dilakukan oleh anak-anak memerlukan teman untuk bermain dan bereksplorasi. Bagi anak-anak bermain dengan teman dapat mengusir kejenuhan dan pembelajaran, hal itu tentunya perlu di dapat di luar rumah. Perasaan terkurung dan pertanyaan kapan semua ini akan bisa menjadi pemicu stress saat pandemi virus corona seperti saat ini. Hasil penelitian menunjukkan bahwa problem yang muncul pada anak-anak usia dini akibat stay at home yaitu :

\section{Stress pada anak}

Berada di rumah saja menjadi upaya yang harus dilakukan semua orang di tengah pandemi corona (COVID-19). Cara ini diharapkan dapat memutus rantai penularan virus. Namun perlu di ketahui berdiam diri di rumah saja ternyata memberi dampak 
negatif pada anak. Salah satu yang cukup terasa menurut Seto Mulyadi (Detik com: 24/20) anak jadi stres. Salah satu penyebab stress anak berdasarkan temuan peneliti yaitu:

\section{Banyak Tugas belajar yang harus di kerjakan oleh anak.}

Seiring dengan 14 hari belajar di rumah, ternyata tugas yang harus dikerjakan anak-anak mereka di rumah cukup banyak, akibatnya selama menjalani sekolah dari rumah, anak-anak bukannya merasa bahagia dan refreshing di rumah. Tetapi merasakan stres yang berlebih dan merasakan beban belajar lebih berat. Guru mengambil langkah mudah dengan memindahkan beban belajar di sekolah ke rumah begitu saja. Akibatnya banyak orang tua yang ikut-ikutan disibukkan mengerjakan tugas sekolah anaknya. Sebagai mana di contohkan oleh orangtua siswa, suyanti menyebut ketika di wawancarai, anaknya pernah diberi tugas untuk membantu bersih-bersih di rumah. Kegiatan ini lantas harus dibuktikan dengan foto, dan dikirim ke guru.(Wijayanti and Akbar 2018).

\section{Cara orangtua mengasuh anak}

Pola asuh orang tua menjadi faktor dominan dalam meredam stress pada anak, jika orang tua salah memberi treatmen/pendampingan pada anak takhayal semakin membebani anak. (Tabi'in, 2020) Tak bisa dipungkiri, orangtua sekarang harus bisa jadi guru di rumah. Orangtua dituntut untuk bisa menjelaskan, menerangkan, dan bahkan akhirnya memaksakan suatu capaian bisa diraih si anak hal ini yang semakin membebani pada anak karena anak di tuntut untuk dapat menyelesaikan pekerjaan belajarnya tanpa melihat aspek psikologis anak.

\section{Orang tua tidak sabar dalam menemani anak belajar dan bermain}

Hasil interview yang dilakukan peneliti pada salah satu orang tua wali dari luqman menuturkan bahwa diakui banyak orang tua dalam menemani belajar kurang sabar sehingga muncul kekesalan dan melampiaskannya pada anak. Sejatinya orang tua harus menjadi figur dalam memberi kesabaran pada anak, hal lain menunjukkan bahwa ternyata orang tua juga sudah merasa jenuh dengan stay at home serta WFH yang di terapkan hal itu memicu ketidak sabaran orang tua dalam menemani anak belajar dan bermain. Sejatinya orang tua harus mengetahui bahwa kesejahteraan psikologis anak, dalam arti anak tidak menjadi cemas atau stres dalam situasi baru. Suasana tetap harus menyenangkan. Perlu disadari bahwa situasi rumah itu, ya, homey, sehingga perlu fleksibel juga.

Sensitifitas Semenjak di tetapkan belajar di rumah sejak pertengahan maret hingga sekarang mei anak anak cenderung mengalami sensitiftas yang meningkat. Hasil penelusuran peneliti menujukkan di sebabkan karena anak-anak jenuh dengan kegiatan-kegiatan yang sangat monoton dan kurangnya bermain dengan temanteman sejawat. Sensitivitas itu terlihat anak sering marah jika terjadi kesalahankesalahan kecil, misal yang di alami dika ketika minta di ambilkan air minum, ketika ibunya mengambilkan air minum agak lama maka anak tersebut sering marah seolah tanpa sebab. Tidak hanya itu masih banyak kejadian lain yang di alami oleh anak-anak. 
Temper -Tantrum juga menjadi salah satu problem yang muncul keitika stay at home pada anak usia dini, ini terlihat dari salah satu anak didik atau siswa TK Puspita an. Ahmad yang mengalami temper tantrum sejak adanya stay at home. Sebelumnya ahmad sebelum adanya virus yang mewabah tergolong anak yang eksploratis suka bermain dengan teman-temanya saat di sekolahan dan tidak memiliki sifat-sifat tamper tantrum akan tetapi semenjak ahmad tidak dapat bergaul dengan teman mainnya karena stay at home ahmad mengalami tekanan psikologis tidak dapat melakukan eksplorasinya bersama teman temanya di tambah banyak kegiatan di rumah dari mulai mengerjakan tugas, mengaji bermain yang serba dilakukan di rumah serta di tambah orang tuanya yang tidak mampu berinovasi dalam mendampingi anak tersebut untuk bermain. Temper trantum atau disebut tantrum, merupakan suatu luapan emosi yang tidak terkontrol pada anak, yang sering muncul pada anak tahap usia 4-6 Tahun. Konflik ini muncul seiring dengan adanya berbagai kemauan anak yang tidak dipahami atau dipenuhi oleh orangtua, sehingga sering kali orang tua merasa kerepotan pada tahap ini (Ubaedy, 2009), hal ini terjadi pada masa pandemi ini ketika anak-anak minta bermain ketetangga dekat atau teman mainnya, hal ini tidak dipenuhi oleh orang tua dengan alasan keamanan. Kemudian dari pada itu anak-anak yang mengalami ini cenderung selalu melampiaskan segala bentuk kemarahannya kepada orang yang ada di sekitarnya. Tingkah laku ini (tantrum) terlihat ketika anak-anak menangis dengan keras, bertirak-teriak, menjerit, memukul-mukul bahkan mengigit, menendang dan mencakar-cakar. (Hayes, 2003).

Perilaku tantrum memang tidak selamanya menjadi hal yang negatif bagi stimulasi perkembangan anak. Hal ini bisa dilihat ketika kita mau menelaah lebih dalam, memiliki hal-hal yang positif, seperti anak memiliki keinginan dalam menunjukkan indepensinya, mengutarakan pendapat, mengeluarkan rasa marah dan frustasi, serta mampu membuat orang tuanya untuk mengerti terhadap kondisi yang ada. (Muttaqin, 2009). Walaupun demikian, bukan berarti bahwa tantrum harus dipuji dan disemangati (encourage). Bila orang tua bertindak keliru dalam mengatasi tantrum, berarti orang tua kehilangan satu kesempatan baik untuk mengajarkan anak tentang bagaimana caranya bereaksi yang wajar terhadap emosiemosi yang normal, misalnya, marah, frustrasi, takut, dan kesal (La Forge, 2002).

Banyak dari orang tua di masa pandemi ini salah memperlakukan anak dan cenderung emosinan sebagaimana kata orang tua ahmad saat diwawancarai mengatakan bahwa orang tua juga sedang WFH (Work From Home) yang mana banyak kerjaan yang harus di selesaikan, sedangkan anak juga sudah mulai jenuh di kasih permainan karena sudah terlalu lama di rumah. Orang tua sering menghadapi kejadian tantrum ini dengan metode atau cara yang kurang baik diantaranya yaitu orang tua cenderung pasrah dan menyerah karena orang tua tidak mau melayani anak, kemudian orang tua menggunakan suara keras saat bersuara atau berkomunikasi dengan anak, hal itu dengan harapan anak dapat merespon secara cepat atas apa yang diperintahkan orang tua. bahkan ada orangtua yang segera memberikan hukuman fisik seperti memukul pantat anak dan mencubit agar tantrum segera berakhir (Surya dan Robert, 2004; Gracinia, 2005). Stay at home

Problematika Stay At Home (Tabi'in) 196 
yang semula bertujuan baik tentunya akan menjadi masalah jika terus dibiarkan terutama pada anak-anak TK Puspita, orang tua menjadi peran utama untuk membuat anak merasa senang dalam melakukan stay at home. Kejadian tantrum akibat kejenuhan ini mempunyai dampak yang bahaya jika salah menyikapinya, Laforge (2002) mengungkapkan apabila perilaku tantrum pada anak terlambat untuk ditangani oleh orang tua, maka perilaku tantrum akan menjadi sifat yang melekat pada anak-anak ketika menjelang dewasa. Dalam hal ini orang tua harus mengambil sikap mengformulasikan penanganan tantrum pada anak yang diakibatkan kejenuhan saat stay at home, yaitu, Orang tua mengenali pola tantrum anak serta meminimalisir terjadinya tantrum pada anak.

\section{Manja atau Tidak mandiri}

Dampak stay at home pada anak sangatlah besar tatkala orang tua kurang kreatif dan inovatif dalam mengatur pola asuh anak. Salah satunya yaitu sikap kemandirian anak. Banyak orang tua wali TK Puspita ini cenderung memenuhi semua keinginan anak dan anak menjadi pasif. Sejak di terapkan stay at home banyak anak- yang terbiasa tidak melakukan apa-apa sendiri, semuanya dilakukan orang tuanya dengan dalih kasih sayang orang tua pada anak, hal ini akan menjadi anak tidak mandiri. Ketidak mandirian otomatis berdampak pada masa depannya. Ketidak mandirian anak terlihat saat anak ketika akan makan, anak memilih disuapi ibu karena ia merasa ada orang tua disampingnya. Begitu pula dengan kemandirian lainnya memaki baju, padahal ketika hari-hari di sekolah guru selalu mengajarkan pada anak didiknya untuk melakukan hal-hal sederhana secara mandiri mulai memakai baju atau celana sendiri, membiasakan makan sendiri dan membereskan tempat main sendiri ketika sudah selesai bermain. Semua hal itu saat di rumah peran anak di ambil orang tuanya. Dan setelah peneliti mewawancarai orang tua ternyata aspek pengetahuan orang tualah yang menjadi faktor penentu kemandirian anak.

\section{Gangguan perilaku /Conduct disorder}

Dampak stay at home yang selanjutnya yaitu munculnya gangguan perilaku pada anak. Gangguan perilaku adalah gangguan serius dalam hal tingkah laku dan emosi yang dapat terjadi pada anak-anak. Anak-anak dengan gangguan perilaku dapat menunjukkan pola tingkah laku yang mengganggu dan penuh kekerasan. Gangguan perilaku yang tidak diatasi pada masa anak-anak dapat berlanjut menjadi gangguan kepribadian pada masa dewasa. Gangguan perilaku pada anak ini muncul karena anak sudah terlalu bosan apa yang dia lakukan di rumah. Hal ini terlihat dari beberapa hal yang muncul akibat gangguan perilaku tersebut berdasarkan observasi dan wawancara oleh peneliti pada anak-anak TK Puspita yang stay at home adalah:

\section{Anak tidak bisa belajar dengan baik}

Ketidak mampuan anak belajar di sini tentunya dipengaruhi oleh faktorfaktor yang ada, salah satunya yaitu kondisi psikologis anak, salah satu aspek psikologis yaitu anak secara tidak langsung tertekan oleh aturan tidak boleh bermain bersama dengan teman-temannya seperti biasanya karena aturan yang diterapkan oleh orang tua dengan alasan keamanan terkait virus corona. 


\section{Perasan anak cepat berubah}

Anak-anak yang mengalami gangguan perilaku ini terlihat perasaannya sering berubah-ubah tanpa adanya sebab yang pasti. Hal ini terlihat saat pengamatan semula anak ingin makan telur tetiba tidak jadi ingin makan yang lain, kemudian semula meminta bermain mobil-mobilan tidak lama tidak jadi dan meminta bermain yang lain. Kondisi seperti inilah yang terjadi pada anak-anak yang terlalu lama stay at home.

\section{Sulit untuk dinasihati}

Anak-anak yang mengalami gangguan perilaku ketika dinasehati sering membatah yang notabennya usia mereka masih 4 sampai dengan 6 tahun, hal ini banyak di temukan peneliti pada anak laki-laki, akan tetapi ada pula anak perempuan yang mengalami hal tersebut. Sebut saja nesya anak berumur 5,5 tahun masuk TK B ini mengalami gangguan perilaku tersebut, hal ini seperti yang di sampaikan oleh ibunya yang mengatakan bahwa anak tersebut sebelum terjadi libur jarang membantah akan tetapi akhir-akhir ini anak tersebut sering membantah jika dinasihati oleh orang tuanya. Ketika ditanya bahwa anak tersebut ingin masuk sekolah biar banyak teman bermain. Hal ini sangat terlihat bahwa anak-anak lakilaki maupun perempuan yang memiliki kejenuhan bisa mengalami hal tersebut.

\section{KESIMPULAN}

Pemberlakuan stay at home untuk pencegahan COVID-19 mendorong aktivitas pembelajaran dilaksanakan secara mandiri di rumah. Termasuk pembelajaran pada anak-anak prasekolah yaitu pada jenjang Taman Kanak-Kanak (TK). Pemberlakukan stay at home menjadi permasalahan yang sangat serius untuk kalangan anak-anak yang mana mereka merasa tidak bisa eksploratif sebagaimana yang seharusnya mereka lakukan untuk menstimulasi aspek perkembanganperkembangan yang ada sebagai anak penjelajah. Stay at home memunculkan problem tersendiri pada anak-anak, yaitu munculnya stress, sensitifitas, anak menjadi manja, dan perubahan tingkah laku, hal itu muncul disaat mereka terlalu lama tinggal dirumah.

\section{DAFTAR PUSTAKA}

Ade Nasihudin Al Ansori. (2020). Belajar di Rumah Akibat Corona COVID-19, Ini Pendapat dan Harapan Anak Indonesia. Liputan6. https://m.liputan6.com/health/read/4224969/b elajar-di-rumah-akibatcorona-covid-19-inipendapat-dan-harapan-anak-indonesia

Aswasulasikin, A. (2020). Persepsi Mahasiswa Terhadap Kuliah Daring dimasa Pandemi Corona Virus Disease (COVID-19). SALAM: Jurnal Sosial dan Budaya Syar- $i, 7(8)$.

Budisetyani, W dan Partiwi, Y. (2013). Emosi Dan Penggunaan Warna Dominan Pada Kegiatan Anak Usia Dini. Jurnal Psikologi Udayana. Vol. 1 . No. 1. H. $160-170$

Problematika Stay At Home (Tabi'in) 198 
Creswell, John W. 2015. Penelitian Kualitatif \& Desain Riset. Yogyakarta : Pustaka Pelajar.

Desmita. (2006). Psikologi Perkembangan. Bandung : Remaja Rosdakarya

Gracinia, J. (2005). Ajari aku solusi praktis untuk 30 perilaku anak yang menjengkelkan. Jakarta: Gramedia.

Hayes, E. (2003). Tantrum: Panduan memahami dan mengatasi ledakan emosi anak. Jakarta : Erlangga.

Laforge.A.E. (2002). Kiat-kiat meredakan badai kerewelan balita anda. Bandung: Kaifa.

Menteri Pendidikan. (2020). Surat Edaran Nomor 3 Tahun 2020 Tentang Pelaksanaan Pendidikan dalam Masa Darurat CoronaVirus (COVID-19).

Miles, B. Mathew dan Michael Huberman. 1992. Analisis Data Kualitatif Buku Sumber Tentang Metode-metode Baru. Jakarta: UIP.

Moleong Lexy J. 2005. Metodologi Penelitian Kualitatif, Bandung: Remaja Rosdakarya

Muttaqin, Z. (2009). Psikologi anak dan pendidikan. Diakses dari http://luluvikar.files.wordpress. com. Dikutip tanggal 13 Maret 2013.

Nahdi, K., Ramdhani, S., Yuliatin, R. R., \& Hadi, Y. A. (2020). Implementasi Pembelajaran pada Masa Lockdown bagi Lembaga PAUD di Kabupaten Lombok Timur. Jurnal Obsesi: Jurnal Pendidikan Anak Usia Dini, 5(1), 177-186.

Nahdi, K., \& Yunitasari, D. (2019). Literasi Berbahasa Indonesia Usia Prasekolah Ancangan Metode Dia Tampan dalam Membaca Permulaan. Jumal Obsesi: Jumal Pendidikan Anak Usia Dini, 4(1), 446-453

Nahdi, K., \& Yunitasari, D. (2019). Inside-outside circle: An early childhood language and literacy development method. International Journal of Innovation, Creativity and Change, 5(6), 325-335.

.Rahmawati Yeni \& Kurniawati Euis, Strategi Pengembangan Kreativitas Pada Anak Usia Taman Kanak-kanak. Jakarta : Kencana.2010

Santrock, J.W. (2007). Perkembangan Anak 2. Alih bahasa oleh Mila Rahmawati. Jakarta : Erlangga

Suryani, Lilis. 2007. "Analisis Permasalahan Pendidikan Anak Usia Dini Dalam Masyarakat Indonesia." $\quad J I V \quad 2 \quad$ (1): $\quad 42-48$. https://doi.org/10.21009/JIV.0201.6.

Surya, S., \& Robert, H. (2004). Panduan lengkap perawatan untuk bayi dan balita. Jakarta: Arcan. 
Tabi' in, A. 2017. "Pengelolaan Pendidikan Karakter Disiplin Anak Usia Dini Studi Kasus Di Al-Muna Islamic Preschool Semarang." AWLADY: Jurnal Pendidikan Anak 3 (1).

Tabi'in, A. 2020. "Pola Asuh Demokratis sebagai Upaya Menumbuhkan Kemandirian Anak di Panti Asuhan Dewi Aminah," 14.

Wijayanti, Rina, and Mochammad Ramli Akbar. 2018. "Asesment Model Strategi Coping Orangtua Murid untuk Permasalahan Anak Usia Dini." Jurnal Inspirasi Pendidikan 8 (1): 79-83. https://doi.org/10.21067/jip.v8i1.2246

Yurianto, Ahmad, Bambang Wibowo, K. P. (2020). Pedoman Pencegahan Dan Pengendalian Coronavirus Disease (COVID-19) (M. I. Listiana Azizah, Adistikah Aqmarina (ed.). 